\section{IN brief}

\section{Ontario's \$100 million draw}

The Canadian province of Ontario will invest an extra CAD $\$ 100$ million ( $\$ 87.4$ million) in the life sciences this year, in a drive to retain scientific talent and advance the region's prosperity. On May 4, John Wilkinson, Minister of Research and Innovation, announced the province's support for "significant collaborative research projects headquartered in Ontario" with a focus on genomics and gene-related research leading to treatments for cancer, diabetes and heart disease, as well as agriculture, environmental protection and clean technologies. Locals fear a hemorrhaging of talent and research across the border, as the US steps up its support for the life sciences, a situation compounded by the Canadian federal government's much-criticized CAD\$148 million cut to the research-funding agencies' budget. The new funds, aimed at academics, are clearly not a panacea, but are seen as a lifeline. "It is definitely the type of investment that makes it easy and attractive to recruit talented investigators both Canadian and non-Canadian," says Benjamin Neel, who in 2007 was recruited from Harvard University Medical School to become director of the Ontario Cancer Institute. "I think I speak for all Ontario scientists when I say we really appreciate and strongly support the provincial government's efforts to promote the knowledge economy, which is the economic future of both the province and the country." The province will support one-third of a project's costs, with the rest coming from private partners and institutional sources. Ontario has also announced a CAD $\$ 3.8$ million injection into the International Regulome Consortium, a Canadian-led genomics effort. Stephen Strauss

\section{Algae trailblazer shuts}

GreenFuel Technologies (Cambridge, Massachusetts), one of the first companies to enter the algal biofuel industry, folded in May-a sign that investors may be starting to weed out the weaker players. GreenFuel raised at least $\$ 33$ million from investors between 2005 and 2008, but in recent months couldn't garner another round of funding. GreenFuel claimed it was a victim of the economy, but some algae researchers say the company's technology simply wasn't economical, and investors had wised up. "It was a crappy business plan," says Stephen Mayfield, a biologist at The Scripps Research Institute in La Jolla and an advisor to Sapphire Energy, an algae company in San Diego. GreenFuel's plan was to grow algae in photobioreactors fed with carbon dioxide from industrial emissions, and produce oil for fuel and other products. But the photobioreactors proved to be twice as expensive as calculated (Nat. Biotechnol. 27, 15-18, 2009) and oil yields fell far short of the quantities GreenFuel had expected. "My bet is investors finally got around to doing the numbers," says Mayfield. GreenFuel's demise may be a sign that the field is maturing. More than 100 algae companies have popped up in the last five years. "In the next year we'll see lots and lots of these companies start to fold," says Mayfield.

Emily Waltz

\title{
Diagnostics firms face new patent claim worries
}

As the debate over Myriad Genetics and gene patents reignites, diagnostics firms face new uncertainties about their intellectual property (IP). The US Supreme Court is gearing up to hear Bilski v. Doll, a case over patenting methods used in commodity trading that could prove critical to biotech, in particular molecular diagnostics. "For years, we had nothing to talk about, and all of a sudden the sky is falling," says David Resnick, a partner and co-practice leader of Boston-based law firm Nixon Peabody's patents division.

The recent lawsuit filed against the $B R C A 1$ and BRCA2 breast cancer gene patents has drawn the most attention. The case, Association for Molecular Pathology, et al. v. U.S. Patent and Trademark Office, et al., pits the Bethesda, Maryland-based Association for Molecular Pathology (AMP), which includes patients, some breast cancer activists and laboratories representing over 100,000 researchers, against the US Patent and Trademark Office (USPTO), in Washington, DC, and the patent ownersMyriad Genetics and the University of Utah Research Foundation, both based in Salt Lake City. AMP et al. claim the patents are invalid and, in a surprise twist, that they violate the First Amendment's guarantee of free speech.

The USPTO has ruled that genes are patentable once isolated and purified. "That is just wrong," says Sandra Park, a staff attorney for the American Civil Liberties Union (ACLU) in Washington, DC- one of the groups arguing against the patents. "We want the patent office to reverse its policy, starting with $B R C A 1$ and 2." The lawsuit claims the patent gives Myriad a monopoly not just on the genes, but on "fundamental pieces of knowledge" as well. That blocks "free exchange of knowledge and ideas," which infringes the First Amendment. Parks points out, however, that the lawsuit is strictly about genes. "We have no problems with patents on tests or therapies."

"The prevailing legal principle is that you cannot patent processes of nature," says Barbara Brenner, executive director of Breast Cancer Action, an advocacy organization located in San Francisco, California, that is in on the lawsuit. "Someone made a mistake 15 years ago, and we want to right that." Not surprisingly, Myriad is saying little about the case. CNN reports that Myriad's executive vice president, General Counsel Richard Marsh, says the company "strongly believes its patents are valid and enforceable and will be upheld by the courts." He adds that the company would

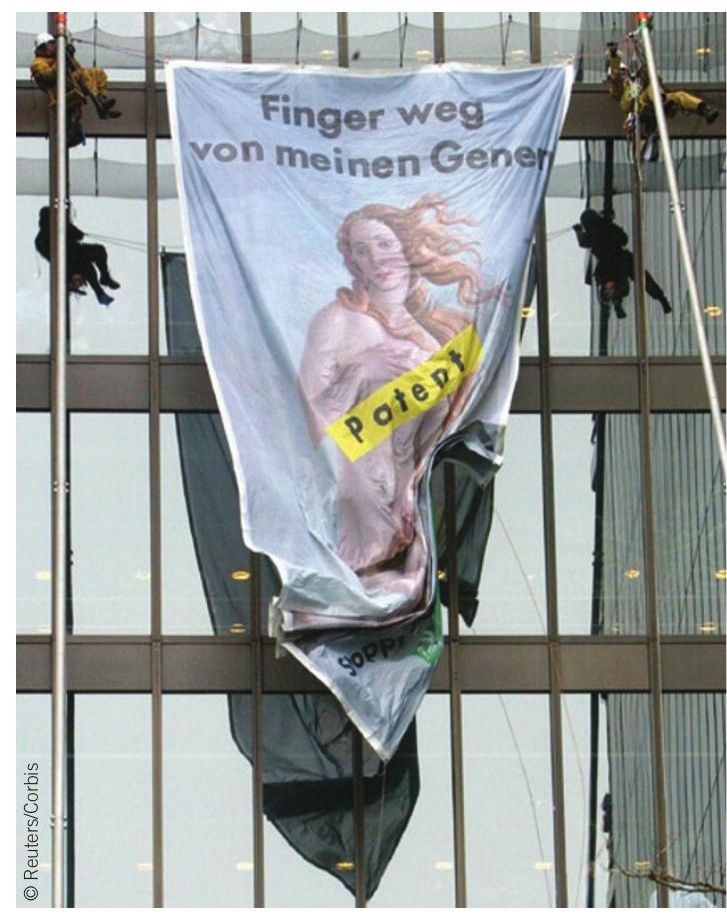

Myriad's patents on $B R C A 1$ and $B R C A 2$ genes have long stirred controversy.

"vigorously defend" its IP and that a 1980 US Supreme Court decision cleared the way for "tens of thousands of genetic and geneticrelated patents" to be granted in the United States.

Indeed, it's estimated that a good $20 \%$ of the genome-and probably the most valuable part-has already been patented. Although gene patents have been hard fought all over the world, they are allowed, to some extent, in almost all countries.

It's no coincidence that the debate has been revived now. "We've wanted to do this for a long time but couldn't get anyone else interested before," says Brenner. Two key trends appear to be responsible: new technologies bumping against old-style patents and the fact that Myriad and one other company, Athena Diagnostics of Worcester, Massachusetts (now part of Thermo-Fisher), are holding such tight rein on their gene patents.

New scientific findings have shaken up the status quo. "At first, they thought it was 'one gene, one disease', but now we know it's much more complex," Park says. For example, $B R C A$ genes are no longer just associated with breast and ovarian cancer, but with prostate and pancreatic cancer too. The breast cancer research 